\title{
Mycale (Aegogropila) magellanica (Porifera: Demospongiae) in the southwestern Atlantic Ocean: endobiotic fauna and new distributional information
}

\author{
LAURA SCHEJTER ${ }^{1,2,3}$, IGNACIO L. CHIESA ${ }^{1,4}$, BRENDA L. DOTI ${ }^{1,4}$ \\ and CLAUDIA BREMEC ${ }^{1,2,3}$ \\ ${ }^{1}$ Consejo Nacional de Investigaciones Científicas y Técnicas (CONICET). \\ ${ }_{2}^{2}$ Instituto Nacional de Investigación y Desarrollo Pesquero (INIDEP), Paseo Victoria Ocampo 1, 7600 Mar del Plata, \\ Argentina. E-mail: schejter@inidep.edu.ar \\ ${ }^{3}$ Instituto de Investigaciones Marinas y Costeras (IIMyC, CONICET-UNMdP). \\ ${ }^{4}$ Departamento de Biodiversidad y Biología Experimental, Facultad de Ciencias Exactas y Naturales, Universidad de \\ Buenos Aires, Ciudad Universitaria, C1428EHA, Buenos Aires, Argentina.
}

SUMMARY: The composition of endobionts in the sponge Mycale (Aegogropila) magellanica at the shelf-break, near 100 $\mathrm{m}$ depth, in the Argentine Sea was studied. We also provide new information on the distribution of M. (A.) magellanica, extending its northern limit to $38^{\circ} 36.02^{\prime} \mathrm{S}$ and $55^{\circ} 44.68^{\prime} \mathrm{W}, 91 \mathrm{~m}$ in the SW Atlantic Ocean. The main Patagonian scallop fishing grounds are located in the shelf-break frontal area of the Argentine Sea. In this area, M. (A.) magellanica plays an important role in providing habitat for at least 23 taxa of small invertebrates, mostly crustaceans (66\% to $96 \%$ of the total number of individuals). On average, this sponge hosted 348 individuals per litre; Aristias cf. antarcticus (Amphipoda) was the most frequent and abundant species. Other organisms commonly found were the isopod Caecognathia sp., the amphipod Leucothoe cf. spinicarpa, the bivalve Hiatella meridionalis and the ophiuroid Ophiactis asperula. As previously demonstrated for other sponges, our study suggests that $M$. (A.) magellanica enhances benthic biodiversity, as it shelters a variety of invertebrate species. In areas of soft and flat substrate, erect and sessile epifauna usually acts as an ecosystem engineer, structuring the architecture of the habitat by increasing the sea-bottom complexity. Mass removal of this fauna due to intense trawling activities on Patagonian scallop beds could have devastating effects on local biodiversity.

Keywords: Mycale (Aegogropila) magellanica, sponge-invertebrate associations, benthic richness, Argentine Sea.

RESUMEN: Mycale (AEgogropila) magellanica (Porifera: Demospongiae) en el Atlántico suroeste: fauna endoBIótiCa Y NUEVOS DATOS DE SU DISTRIBUCIÓN. - Se estudió la composición de endobiontes de la esponja Mycale (Aegogropila) magellanica, recolectada en el área del talud del Mar Argentino, a una profundidad promedio de $100 \mathrm{~m}$. Se presenta también nueva información sobre la distribución de $M$. (A.) magellanica, extendiendo su límite norte hasta los 38³6.02'S y 5544.68'W, $91 \mathrm{~m}$ en el Atlántico Sudoccidental. En el Mar Argentino, los principales bancos de vieira patagónica están situados en el borde externo de la plataforma, en el área frontal del talud. En esta región, $M$. (A.) magellanica juega un papel importante al proveer hábitat para al menos 23 taxones de invertebrados pequeños, en su mayoría crustáceos (66 al $96 \%$ del total de individuos). En promedio, esta esponja alberga 348 individuos por litro de esponja, siendo Aristias cf. antarcticus (Amphipoda) la especie más frecuente y abundante. Otros organismos hallados con frecuencia fueron el isópodo Caecognathia sp., el anfípodo Leucothoe cf. spinicarpa, el bivalvo Hiatella meridionalis y la ofiura Ophiactis asperula. Tal como se ha encontrado en otras esponjas, nuestros resultados sugieren que $M$. (A.) magellanica enriquece la biodiversidad local al proveer refugio a una gran variedad de invertebrados bentónicos. En áreas de sustrato blando, la epifauna eréctil y sésil estructura la arquitectura del hábitat, aumentando la complejidad del fondo. La extracción de esta fauna a causa de una intensa actividad pesquera en los bancos de la vieira patagónica tendría efectos perjudiciales sobre la biodiversidad local.

Palabras clave: Mycale (Aegogropila) magellanica, asociaciones esponja-invertebrados, riqueza bentónica, Mar Argentino. 


\section{INTRODUCTION}

The sponge Mycale (Aegogropila) magellanica (Ridley, 1881) is distributed in Antarctic, sub-Antarctic, Chilean and Argentine waters (van Soest et al. 2011). In this last region, $M$. (A.) magellanica is one of the most widely distributed, $39^{\circ} 10^{\circ} \mathrm{S}$ and $56^{\circ} 20^{\prime} \mathrm{W}$ being its northern distribution limit in the Atlantic (López Gappa and Landoni 2005) (Fig. 1). In spite of its wide distribution, relatively frequent finding and easy identification compared with other sponges in the shelfbreak frontal area of Argentina (Schejter et al. 2006, Bertolino et al. 2007), no studies have been performed on this species, besides the original description and subsequent faunistic records.

The relation between sponges and their associated organisms ranges from accidental or intentional commensalism to predation, mutualism or parasitism (Sará and Vacelet 1973, Pawlik 1983, Wendt et al. 1985, Wulff 2006, Winfield and Ortiz 2010, and references therein). Endobiotic taxa registered worldwide comprise representatives of up to 11 phyla (Rützler 1976). The most common endobionts are protozoans, diatoms, cnidarians, polychaetes, crustaceans, echinoderms and other invertebrates such as pycnogonids, platyhelminths, sipunculids and nemertins, but they also include fishes (see Supplementary material Appendix 1 for examples; and Wulff 2006 for review). Klitgaard (1995) suggested that the majority of the fauna associated with sponges in temperate/cold waters is

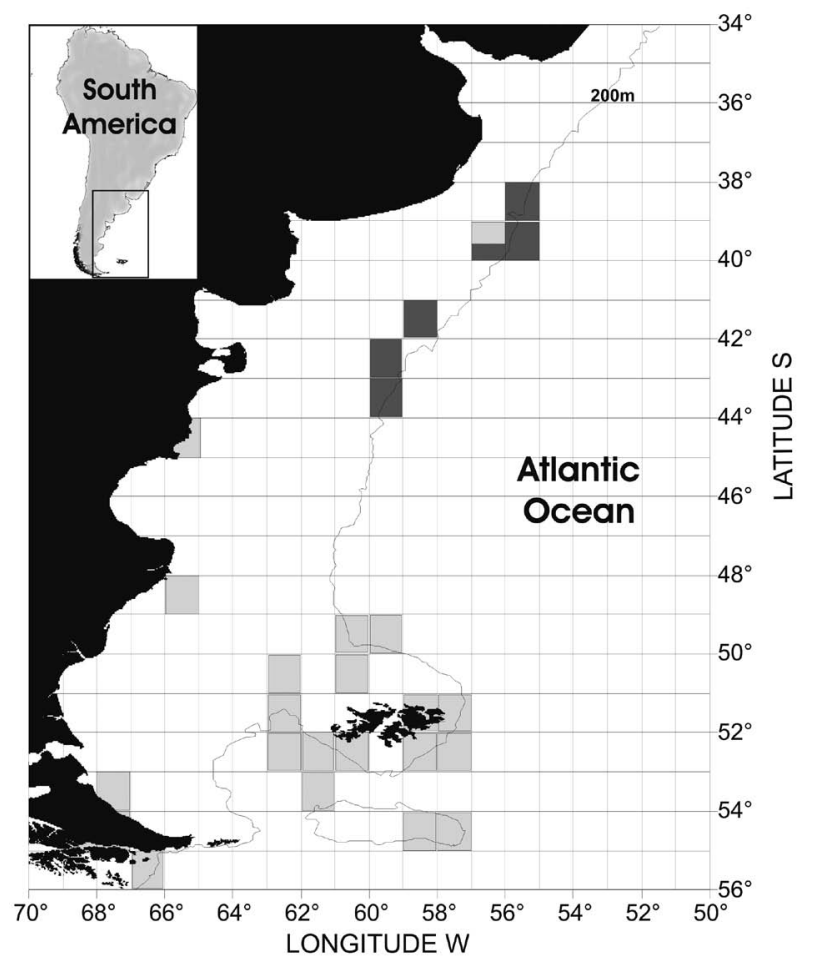

FIG. 1. - Distribution of Mycale (A.) magellanica (Ridley, 1881) in the Argentine Sea. Light shadow areas represent previous records, dark shadow areas represent sampling sites of the present study. composed of facultative inhabitants, while those of the warm tropical waters are apparently obligate sponge associates. Endobionts obtain refuge, direct or indirect sources of food and sites for reproduction, while they may contribute to host defence against predators or sediment removal (Wendt et al. 1985, Saffo 1992, Thiel 2000, Poore et al. 2000, Wulff 2006).

The kind of endobionts hosted by a species is related to the morphology and the chemical defence of the host sponge (e.g. Neves and Omena 2003, Skilleter et al. 2005), among other biotic interactions (e.g. Koukouras et al. 1992). Rützler (1976) found a positive relation of the sponge canal volume to total mass of endofauna, but many other studies showed no relationship between abundances of endobionts and volume of the sponge (Koukouras et al. 1985, Ota et al. 2008), presumably due to the high variability in associated endobiont fauna among sponge samples.

The total endofauna of some sponges from the North Atlantic, Mediterranean, East and West Pacific and Antarctic waters has been studied, but only a few SW Atlantic species have been studied to date: Hymeniacidon sanguinea (Grant, 1827) (Cuartas and Excoffon 1993), Mycale (Zygomycale) angulosa (Duchassaing and Michelotti, 1864) (as Z. parishii) (Duarte and Nalesso 1996) and Mycale (Carmia) microsigmatosa Arndt, 1927 (Ribeiro et al. 2003). However, several other, less comprehensive studies have reported sponge associates worldwide (Supplementary material Appendix 1).

López Gappa and Landoni (2005) reported the presence of 196 species in the Argentine Sea; the spongeinvertebrate associations of many of these species have not been studied yet. In this paper we studied the endobiotic fauna of Mycale (A.) magellanica and we compared these results with those of other sponge species. We discuss our findings in relation to the well-known benthic richness of the study area. Additional records for the distribution of the sponge M. (A.) magellanica in the shelf-break frontal area of the Argentine Sea are also given.

\section{MATERIALS AND METHODS}

Samples for ecological purposes (more than 100 samples consisting of a 10-litre volume each) are collected as a routine procedure during Patagonian scallop Zygochlamys patagonica stock assessment cruises performed yearly by the Instituto Nacional de Investigación y Desarrollo Pesquero (INIDEP). These evaluation cruises are carried out in the shelf-break frontal area of Argentina, SW Atlantic Ocean, a region that supports the scallop fishery. General samplings during the assessment consist of 10-minute trawling or dredging (depending on the vessel) tows (1 tow per site) at a speed ranging between 3.5 and 4 knots. As a standard procedure, scallop stock assessment samples are processed on-board while ecological samples are frozen and then sorted at the INIDEP laboratory. The 
TABle 1. - Location of the sampling sites of Mycale (Aegogropila) magellanica (Ridley, 1881). * Samples used for endofauna composition; \# Northernmost record of the species.

\begin{tabular}{|c|c|c|c|c|c|}
\hline Sample $\mathrm{N}^{\mathrm{o}}$ & Latitude (S) & Longitude (W) & Depth (m) & Date & Cruise Code \\
\hline 1 & $43^{\circ} 25.00^{\prime}$ & $59^{\circ} 48.78^{\prime}$ & 105 & July 2004 & cc1104 - L62 \\
\hline 2 & $39^{\circ} 40.52^{\prime}$ & $56^{\circ} 12.28^{\prime}$ & 90 & July 2007 & cc0507 - L43 \\
\hline 3 & $41^{\circ} 41.96^{\prime}$ & $58^{\circ} 03.10^{\prime}$ & 97 & July 2007 & cc0507 - L7 \\
\hline 4 & $39^{\circ} 00.54^{\prime}$ & $55^{\circ} 41.82^{\prime}$ & 117 & August 2004 & cc1304 - L35 \\
\hline 5 \# & $38^{\circ} 36.02^{\prime}$ & $55^{\circ} 44.68^{\prime}$ & 91 & August 2004 & cc1304 - L69 \\
\hline 6 & $43^{\circ} 25.00^{\prime}$ & $59^{\circ} 49.78^{\prime}$ & 105 & July 2004 & cc1104 - L62 \\
\hline 7 & $38^{\circ} 50.00^{\prime}$ & $55^{\circ} 35.83^{\prime}$ & 117 & July 2002 & cc1002 - L47 \\
\hline 8 & $38^{\circ} 50.00^{\prime}$ & $55^{\circ} 35.83^{\prime}$ & 117 & July 2002 & cc1002 - L47 \\
\hline 9 & $39^{\circ} 35.16^{\prime}$ & $56^{\circ} 01.22^{\prime}$ & 105 & June 2003 & cc0203 - L2 \\
\hline 10 & $42^{\circ} 20.10^{\prime}$ & $59^{\circ} 04.28^{\prime}$ & 94 & June 2003 & cc0203 - L60 \\
\hline $11 *$ & $39^{\circ} 43.47^{\prime}$ & $56^{\circ} 06.55^{\prime}$ & 105 & July 2009 & cc1009 - L1 \\
\hline $12 *$ & $39^{\circ} 43.47^{\prime}$ & $56^{\circ} 06.55^{\prime}$ & 105 & July 2009 & cc1009 - L1 \\
\hline $13 *$ & $39^{\circ} 43.47^{\prime}$ & $56^{\circ} 06.55^{\prime}$ & 105 & July 2009 & cc1009 - L1 \\
\hline $14 *$ & $41^{\circ} 50.15^{\prime}$ & $58^{\circ} 08.34^{\prime}$ & 106 & July 2008 & MT0108 - L64 \\
\hline $15 *$ & $41^{\circ} 51.48^{\prime}$ & $58^{\circ} 09.89^{\prime}$ & 103 & July 2008 & MT0108 - L63 \\
\hline $16 *$ & $39^{\circ} 24.72^{\prime}$ & $55^{\circ} 56.95^{\prime}$ & 107 & July 2009 & cc1009 - L6 \\
\hline
\end{tabular}

majority of the invertebrate species are identified to specific level during the analysis of the ecological samples in the laboratory. However, considering that the identification of groups such as ascidians, sponges and bryozoans is very difficult and time consuming, these organisms are usually grouped into single major taxa for the community assessment purposes (e.g. Schejter and Bremec, 2007b). Samples or vouchers of these organisms are often preserved for taxonomic and/or ecological studies. Sponges, particularly, could represent a variable percentage of the community that averaged 10\% in biomass (Bremec and Lasta, 2002). When their contribution in biomass to the total community is considered relevant (although in relative terms), we keep vouchers or sub-samples of the morphospecies for subsequent analysis.

In relation to the objectives of the present study, while sorting ecological samples, we selected Mycale (A.) magellanica specimens from benthic community samples collected at 12 sites (localities are given in Table 1) where a conspicuous biomass of sponges was registered. Owing to the sampling methods with trawls and dredges, organisms are frequently collected broken or damaged. In consequence, the selection of these 12 samples does not mean that M. magellanica was absent at the other sampled sites, although the species remained unidentified during routine sorting. The biggest sponge pieces collected were separated and dissected for the current study: six sponge pieces between 340 and $660 \mathrm{~g}$ wet weight totalling $2.7 \mathrm{~kg}$, from four localities between $39^{\circ} 24^{\prime} \mathrm{S}-41^{\circ} 51^{\prime} \mathrm{S}$ and $55^{\circ} 56^{\prime} \mathrm{W}-58^{\circ} 09^{\prime} \mathrm{W}$ and between 103 and $107 \mathrm{~m}$ depth. Each sponge piece was first weighed (wet weight) and the volume was determined by water displacement. Then, the sponge piece was cut, disaggregated and examined under a binocular microscope at the Benthos Laboratory (INIDEP). All the endobionts found inside the sponge were sorted, counted and identified to the lowest taxonomic level possible.

Identification of the sponge species was done using the classical procedure based on spicules and skeleton architecture observations, according to Rützler (1978). Scanning electron microscope (SEM) was also used for the observation of spicule morphology.

\section{RESULTS}

The studied specimens of Mycale (A.) magellanica were characterized by a massive or nearly tubular subcylindrical shape, sometimes attached to Zygochlamys patagonica old shells, presumably the original settlement substrate in many cases (Fig. 2A). Sizes of the different types of spicules were quite constant among specimens: i) mycalostyles, straight or slightly curved, 410 to $632 \mu \mathrm{m}$ long (mean: $521 \mu \mathrm{m}$ ) and $10 \mu \mathrm{m}$ thick (Fig. 2D); ii) anisochelae, three size categories (Fig. 2E): large anisochelae 62.5 to $80 \mu \mathrm{m}$ long (mean: 71.25 $\mu \mathrm{m})$ (rare or uncommon in some specimens), intermediate ones 32.5 to $46 \mu \mathrm{m}$ long (mean: $24.75 \mu \mathrm{m}$ ), and small ones 20 to $30.6 \mu \mathrm{m}$ long (mean: $25.3 \mu \mathrm{m}$ ); and iii) microxea 47.5 to $76.5 \mu \mathrm{m}$ long (mean: $62 \mu \mathrm{m}$ ) (Fig. 2F) (measurement values were based on approximately 30 spicules of each type).

Mycale (A.) magellanica was found at new locations along the Argentine shelf-break, these new records extend the distribution of this species northwards (sample $\mathrm{N}^{\mathrm{o}} 5$, 38 36.02' $\mathrm{S}$ and 55 $44.68^{\prime} \mathrm{W}, 91 \mathrm{~m}$ ) (Table 1, Fig. 1).

Six sponge pieces were dissected (wet weight: $369,555,338,660,417$ and $355 \mathrm{~g}$ ) and a total of 849 endobiont individuals were sorted (Table 2). Considering water displacement measures, in general $1 \mathrm{~g}$ of sponge corresponds to a volume of $\sim 1 \mathrm{ml}$ (in all six pieces measured). Hence, on average, the sponge $M$. (A.) magellanica had a mean density of $~ 348$ individuals per litre (or kilogram). Twenty three taxa grouped into five major groups (Crustacea, Mollusca, Echinodermata, Polychaeta, and Sipunculida) were identified. Crustaceans, mainly Amphipoda and Isopoda, reached between $66 \%$ and $96 \%$ of the total number of individuals inhabiting the sponges. The most frequent and abundant species were the amphipod Aristias cf. antarcticus Walker, 1906 and the isopod Caecognathia 


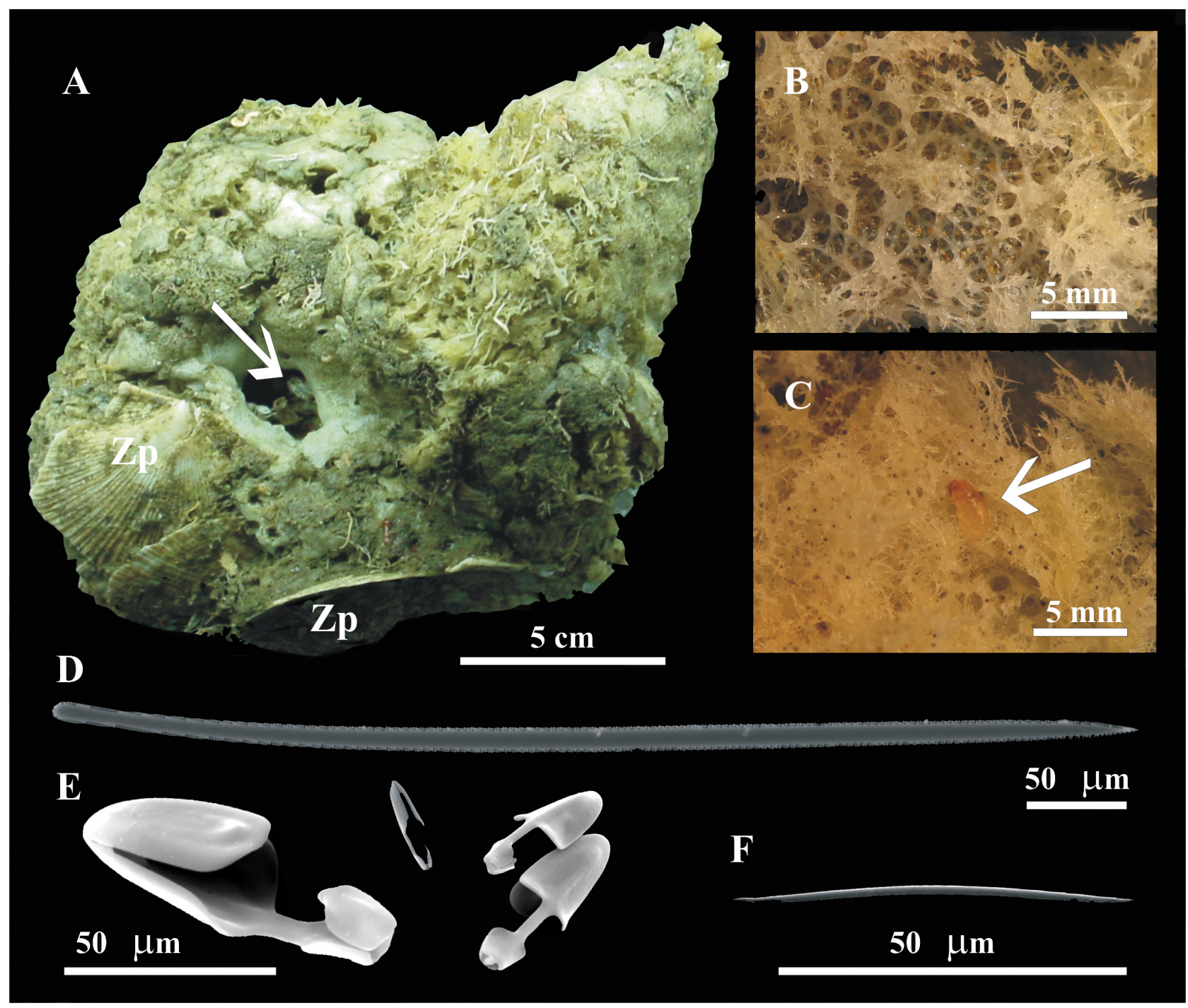

Fig. 2. - Mycale (A.) magellanica (Ridley, 1881). A, macroscopic view of one specimen; Zp, Zygochlamys patagonica old shells; arrow shows individuals of Hiatella meridionalis bysally attached in a depression of the sponge. B, C, internal structures of M. (A.) magellanica; arrow shows a specimen of Aristias cf. antarcticus. Spiculation (SEM images): D, mycalostiles; E, anisochelae; F, microxea.

sp. For both species, adult males, brooding females and juveniles were found. Four other species of amphipods and three of isopods were recorded in lower abundance (Table 2).

The structure, morphology and internal architecture of $M$. (A.) magellanica were very heterogeneous in each single piece (see Fig. 2B, C). Usually the basal part was compact and intricate, and no endobionts were detected (except for a few bivalves identified as Hiatella meridionalis (d'Orbigny, 1846) and some ophiuroids). From the base to the surface, the sponge tissues displayed less dense and softer structures that hosted the majority of the amphipods, isopods and other faunal components (Fig. 2D). Living $H$. meridionalis were found in holes, depressions or crevices of the sponge. However, a few empty shells were also recorded completely embedded inside sponge tissues.
Other endobiotic organisms recorded were the echinoderms Ophiactis asperula (Philippi, 1858), Ophiura lymani (Ljungman, 1871), Ophiacantha vivipara Ljungman, 1870 and Pseudocnus dubiosus (Semper, 1868); polychaetes of at least three families (Spionidae, Polynoidae, Phyllodocidae); and the decapod Nauticaris magellanica (A. Milne Edwars, 1891). Among them, ophiuroids were the most common (Table 2). Polychaetes were poorly preserved due to the freezing/ melting process, so their main morphological features for specific identification were damaged.

\section{DISCUSSION}

This study is the first attempt to elucidate the composition of endofauna (excluding bacterial or fungal symbionts) in sponges from the deep waters of the Argentine Sea. In this regard, it is important to mention 
TABLE 2. - Taxa and number of individuals associated with Mycale (Aegogropila) magellanica (Ridley, 1881) in the studied frozen samples. Location for each sample is given in Table 1. (A) Amphipoda, (I) Isopoda, (D) Decapoda, (O) Ophiuroidea, (H) Holothuroidea.

\begin{tabular}{|c|c|c|c|c|c|c|}
\hline Taxa / Sample $N^{\circ}$ & 11 & 12 & 13 & 14 & 15 & 16 \\
\hline \multicolumn{7}{|l|}{ Crustacea } \\
\hline Aristias cf. antarcticus (A) & 163 & 153 & 152 & 12 & 9 & 18 \\
\hline Leucothoe cf. spinicarpa (A) & & & & 7 & 6 & 9 \\
\hline Seba cf. saundersii (A) & 25 & 18 & 23 & & 3 & 5 \\
\hline Colomastix bastidai (A) & & & & 7 & & \\
\hline Liljeborgia sp. (A) & & & & 1 & & \\
\hline Caecognathia sp. (I) & & 2 & & 37 & 1 & 61 \\
\hline Fissarcturus patagonicus (I) & 2 & & & & & \\
\hline Acanthoserolis schythei (I) & & 1 & & & & \\
\hline Iathrippa sp. (I) & 1 & 1 & 1 & & & \\
\hline Nauticaris magellanica (D) & 1 & & & & & \\
\hline \multicolumn{7}{|l|}{ Mollusca } \\
\hline Hiatella meridionalis & 1 & & 2 & 1 & 9 & 15 \\
\hline Bivalvia unidentified & & & & 1 & & \\
\hline Gastropoda unidentified & & & & & & 1 \\
\hline \multicolumn{7}{|l|}{ Echinodermata } \\
\hline Ophiactis asperula $(\mathrm{O})$ & 20 & 7 & 20 & 1 & & 8 \\
\hline Ophiacantha vivipara $(\mathrm{O})$ & 9 & 3 & 2 & & & \\
\hline Ophiura lymani $(\mathrm{O})$ & & 3 & 1 & & & \\
\hline Pseudocnus dubiosus $(\mathrm{H})$ & 2 & 3 & 3 & 1 & & \\
\hline \multicolumn{7}{|l|}{ Polychaeta } \\
\hline Spionidae & 2 & 2 & 2 & & & \\
\hline Polynoidae & 1 & 1 & & & & 1 \\
\hline Phyllodocidae & & & 1 & & & \\
\hline Polychaeta unidentified 1 & & 1 & & & & 1 \\
\hline Polychaeta unidentified 2 & & 3 & & & & \\
\hline \multicolumn{7}{|l|}{ Sipunculida } \\
\hline Sipunculida unidentified & & & & & & 1 \\
\hline \multicolumn{7}{|l|}{ Others } \\
\hline Unidentified egg capsules & & & & & 1 & \\
\hline Total & 227 & 198 & 207 & 68 & 29 & 120 \\
\hline Wet Weight (g) & 338 & 369 & 555 & 660 & 417 & 355 \\
\hline Density (per litre) & 671.6 & 536.6 & 372.9 & 103.0 & 69.5 & 338.0 \\
\hline
\end{tabular}

that the species Mycale (Aegogropila) magellanica has been previously recorded in the Argentine Sea, mainly in South Patagonian waters, around the Malvinas Islands with scattered records from the Beagle channel and coastal waters of the provinces of Tierra del Fuego and Chubut. Until now, there was only one record from waters off Buenos Aires province (see López Gappa and Landoni 2005). Our results extend the distribution of this species northwards in the SW Atlantic Ocean (Fig. 1).

Mycale (A.) magellanica seems to be important in providing habitat for at least 23 taxa of small invertebrates. Crustaceans were the most important group in abundance and diversity in this study. It is noticeable from the general literature that, among amphipods, members of the Aristiidae, Colomastigidae, Leucothoidae and Sebidae are known to be frequent endobionts of sponges and other sessile invertebrates (LeCroy 2009, Thomas and Klebba 2007, Winfield et al. 2008, White and Thomas 2009, Winfield and Ortiz 2010, Kilgallen 2010, and references therein). However, the species collected in the present study had not been previously recorded inside sponges in the Argentine Sea (see López Gappa et al. 2006, De Broyer et al. 2007).
Until this study, Colomastix bastidai Alonso de Pina, 1993 was only known from the type locality, a position adjacent to the new records mentioned herein (see López Gappa et al. 2006, Table 3). Our finding of C. bastidai represents the second record of the species in Argentine waters. Leucothoe spinicarpa (Abildgaard, 1789) has been reported from polar, temperate, and tropical waters (Thiel 2000). In the Argentine Sea, several records of L. spinicarpa have been reported, many of them in the Magellanic Biogeographic Region and only one in the Argentine Biogeographic Region (see López Gappa et al. 2006). However, according to De Broyer et al. (2007), the Southern Ocean records of $L$. spinicarpa probably belong to one or more southern species. Because of the need for a revision of this species and in order to avoid more taxonomic confusion, we prefer to keep the denomination of Leucothoe cf. spinicarpa. Similarly, Aristias antarcticus Walker, 1906 has been cited from the Malvinas Islands in the Argentine Sea, and it is also widely distributed in Antarctic and sub-Antarctic waters (López Gappa et al. 2006, De Broyer et al. 2007). The systematics of the southern Aristias spp. is in disarray and all previous records of $A$. antarcticus require confirmation (Kilgal- 
len 2010). Therefore, we also keep the denomination of Aristias cf. antarcticus. Because of the wide geographic distribution of Seba saundersii Stebbing, 1875 (in the southern Argentine Sea, sub-Antarctic and Antarctic waters) and the poorly preserved condition of the specimens examined, we identified them as Seba cf. saundersii. For both genera, Aristias and Seba, the new records presented herein are the northernmost known in the Argentine Sea (see López Gappa et al. 2006).

Among the isopods, the second most important group of endobiont crustaceans found, the species Caecognathia sp. (Gnathiidae), was recorded in high abundances. Caecognathia antarctica (Studer, 1884) is the only species of gnathiid isopod reported from the Argentine Sea. The specimens found in our samples most probably belong to this species; however, since Studer (1884) briefly described $C$. antarctica based on a single juvenile, it is not possible to identify this species with certainty. The life cycle of gnathiid isopods involves a parasitic larval phase and a non-feeding adult phase (Monod 1926). The resting larvae and the adult stages are usually found in sponges, tubes of serpulid worms, coral rubble or sediment cavities (Monod 1926, Upton 1987, Wägele 1988, Klitgaard 1997, Smit and Davies 2004). Almost all the specimens of Caecognathia sp. obtained in our samples were males. The lower abundance of females in sponges was also reported by Smit et al. (2003) and Barnard (1914); the latter author found the females inhabiting the tubes of serpulid worms. Three other species of isopods were found in the studied sponge, Fissarcturus patagonicus (Ohlin, 1901), Acanthoserolis schythei (Lütken, 1858) and Iathrippa sp., but each species was represented by one or two individuals. Klitgaard (1995) pointed out that owing to sampling procedures, contamination of the sponge with foreign fauna could be expected. Since these three isopod species were recorded in very low densities and none of them were reported as sponge associates, the finding of these species on M. (A.) magellanica can be considered accidental.

The finding of juvenile stages and brooding females of Aristias cf. antarcticus and Caecognathia sp., although in low abundances, shows that at least a couple of species have a close relationship with $M$. (A.) magellanica, and part of their life cycles probably takes place inside the sponge, as is already known for gnathiids.

In the study area, where the main Patagonian scallop (Zygochlamys patagonica) fishing grounds are located (the shelf-break frontal area), general knowledge on the biodiversity of the small-sized taxa is very scarce. The species composition of this benthic fraction (bigger than $1 \mathrm{~mm}$ ) was recently assessed by means of samples taken with Picard dredge (Sánchez et al. 2011). In coincidence with our results, these authors also found that crustaceans were the most diversified group. The biological material studied by these authors and our present samples come from nearby locations. Only the genus Iathrippa (Isopoda, Asellota, Janiridae) is common to both habitats, although its finding in M.(A.) magellanica could be incidental. Nonetheless, many other crustaceans (especially Lysianassidae spp.) and polychaetes were identified to family level by Sánchez et al. (2011), which could indicate a higher species overlapping between the two studies.

The molluscs and echinoderms species identified herein (see Table 2) are conspicuous components of the Patagonian scallop epibenthic assemblage (Bremec and Lasta 2002, Bremec et al. 2003, Schejter et al. 2008). Hiatella meridionalis (d'Orbigny, 1846) (largely misidentified as $H$. solida (Sowerby, 1834) (see Simone and Penchaszadeh 2008)) is a common bivalve found attached to either rocks or invertebrates, including Z. patagonica (Schejter and Bremec 2007a). In the SW Atlantic, similar records were found in Brazilian waters: $H$. arctica Linnaeus, 1767 was mentioned as an endobiont in Mycale (Zygomycale) angulosa (Duchassaing and Michelotti, 1864) (as Zygomycale parishii) and Mycale (Carmia) microsigmatosa Arndt, 1927, at nearly $23^{\circ} \mathrm{S}$ (Duarte and Nalesso 1996, Ribeiro et al. 2003). Regarding echinoderms, the genus Ophiactis and the species Ophiura lymani are shared between Brazilian and Argentine Mycale species; Ophiactis savignyi (Müller and Troschel, 1842) and Ophiura lymani Ljungman, 1871 were present in Brazilian sponge species, and even dominant in $M$. (Z.) angulosa (Duarte and Nalesso 1996). Although the reduction in predation pressure is granted by chemically protected hosts such as sponges (Majer et al. 2009), which give a favourable habitat to shelter ophiuroid species (Neves et al. 2007), they were not numerically dominant in our samples.

Other infaunal groups that also appeared in low abundance in the studied sponges were polychaetes and sipunculids (only six taxa, see Table 2). Polychaetes are usually one of the dominant groups in sponges (see Supplementary material Appendix 1). A clear relationship between faunal densities and sponge morphology was established by comparing many studies and, for example, in the case of a syllid species, it was reported that lobate sponge species are able to grow faster than massive ones, supporting higher densities of worms (Neves and Omena 2003). Considering the endofauna hosted by other Mycale species (Duarte and Nalesso 1996, Ribeiro et al. 2003, Table 1), in which polychaetes were the dominant group in one of the species but crustaceans were dominant in the other one, it remains unclear whether the morphology or internal architecture of $M$. (A.) magellanica could be responsible for hosting only low densities of polychaetes but high densities of crustaceans.

In general, the highest endobiont richness was found in sponges at low depths and low latitudes (warmest waters) (Supplementary material Appendix 1). The highest endobiont richness could be found in Aplysina aerophoba Nardo, 1883, Sarcotragus fasciculatus (Pallas, 1766) and Agelas oroides (Schmidt, 1864) from the Aegean Sea, with more than 100 associated species each. Considering only the Mycale genus, our 
species showed the lowest endobiont richness, in accordance with the highest latitude and depth.

The shelf-break frontal area in the Argentine Sea is one of the most productive ecosystems in the SW Atlantic Ocean (Acha et al. 2004, Bogazzi et al. 2005) as a consequence of high levels of nutrients (Rivas 2006, Romero et al. 2006). This region is dominated by soft-bottoms (sand and mud), like more than $70 \%$ of the Argentinean continental shelf (Parker et al. 1997). In these habitats, epibiotic relationships are known to increase the specific diversity by providing substrate for the attachment of sessile species, given the lack of rocks or hard bottoms (Schejter and Bremec 2007a, Schejter et al. 2011). Our study thus shows that the sponges themselves also enhance benthic biodiversity, as they are able to shelter a variety of invertebrate species. The endobiont richness is a valuable contribution to local biodiversity, though the values found in $M$. (A.) magellanica are smaller than those shown by other more tropical sponge species.

In soft and flat substrates, erect and sessile epifauna usually play the role of ecosystem engineers, as they structure the architecture of the sea bottom by increasing its complexity. Mass removal of this fauna could have devastating effects on local biodiversity (Coleman and Williams 2002, Abdo 2007). Trawling and dredging activities are the main causes of loss of erect and sessile epifauna (National Research Council 2002, Bremec et al. 2000, 2008). Therefore, fishing activities on the Patagonian scallops beds could affect the settlement of $M$. (A.) magellanica, thus leading to the loss of associated endobionts.

\section{ACKNOWLEDGEMENTS}

The authors thank the crews of the RV Capitán Canepa and FV Miss Tide. L.S. thanks Barbara Calcinai for help and assistance in obtaining SEM images. We would also like to thank INIDEP librarians for their help with literature acquisition and Natalia Alberico for her revision of the manuscript. This study was partially supported by the Instituto Nacional de Investigación y Desarrollo Pesquero (INIDEP), the Consejo Nacional de Investigaciones Científicas y Técnicas (CONICET), grants PICT 2007 2200, PICT 2008 1119, PIP 11220090100244 and PIP 11220090100375, and Universidad de Buenos Aires (UBA) grant X190. This is INIDEP Contribution $\mathrm{N}^{\circ} 1757$.

\section{REFERENCES}

Abdo D.A. 2007. Endofauna differences between two temperate marine sponges (Demospongiae; Haplosclerida; Chalinidae) from southwest Australia. Mar. Biol. 152: 845-854.

Acha E.M., Mianzan H.W., Guerrero R.A., Favero M., Bava J. 2004. Marine fronts at the continental shelves of austral South America. Physical and ecological processes. J. Mar. Sys. 44: 83-105.

Barnard K.H. 1914. Contributions to the Crustacean fauna of South Africa. 3. Additions to the marine Isopoda with notes on some previously incompletely known species. Ann. S. Afr. Mus. 10: 325-442.
Bavestrello G., Sará M. 1992. Morphological and genetic differences in ecologically distinct populations of Petrosia (Porifera, Demospongiae). Biol. J. Lin. Soc. 47(1): 49-60.

Bertolino M., Schejter L., Calcinai B., Cerrano C., Bremec C. 2007. Sponges from a submarine canyon of the Argentine Sea. In: Márcio R., Custódio G., Lôbo-Hajdu E.H., Muricy G. (eds.) Porifera Research: Biodiversity, Innovation and Sustainability. Museu Nacional, Río de Janeiro, pp. 189-201.

Bogazzi E., Baldoni A., Rivas A., Martos P., Reta R., Orensanz J.M., Lasta M., Dell'Arciprete P., Werner F. 2005. Spatial correspondence between areas of concentration of Patagonian scallop (Zygochlamys patagonica) and frontal systems in the southwestern Atlantic. Fish. Oceanogr. 14: 359-376.

Bremec C.S., Lasta M.L. 2002. Epibenthic assemblage associated with scallop (Zygochlamys patagonica) beds in the Argentine shelf. Bull. Mar. Sci. 70: 89-105.

Bremec C., Brey T., Lasta M., Valero J., Lucifora L. 2000. Zygochlamys patagonica beds on the Argentinian shelf. Part I: Energy flow through the scallop bed community. Archive Fish. Mar. Res. 48: 295-303.

Bremec C., Marecos A., Schejter L., Lasta M. 2003. Guía técnica para la identificación de invertebrados epibentónicos asociados a los bancos de vieira patagónica (Zygochlamys patagonica) en el Mar Argentino. Publicaciones Especiales INIDEP, Mar del Plata, 28 pp.

Bremec C., Escolar M., Schejter L., Genzano G. 2008. Primary settlement substrate of scallop Zygochlamys patagonica (King and Broderip, 1832) (Mollusca: Pectinidae) in fishing grounds in the Argentine Sea. J. Shellfish Res. 27: 273-280.

Castritsi-Catharios J., van Soest R.W.M., Kefalas E., Vacelet J. 2011. Revised description of a poorly known Mediterranean Dictyoceratid bath sponge, Spongia (Spongia) zimocca (Schmidt, 1862) (Porifera: Demospongiae: Dictyoceratida). Zootaxa 2812: 41-62.

Coleman F.C., Williams S.L. 2002. Overexploiting marine ecosystem engineers: potential consequences for biodiversity. Trends Ecol. Evol. 17: 40-44.

Cook S. de C., Bergquist P. 2002a. Family Spongiidae Gray, 1867. In: Systema Porifera: A Guide to the Classification of Sponges. Hooper J.N.A., Van Soest R.W.M (eds.). New York, Kluwer Academic/Plenum Publishers, pp. 1051-1060.

Cook S. de C., Bergquist P. 2002b. Family Irciniidae Gray, 1867. In: Systema Porifera: A Guide to the Classification of Sponges. Hooper J.N.A., Van Soest R.W.M (eds.). New York, Kluwer Academic/Plenum Publishers, pp. 1022-1027.

Cuartas E.I., Excoffon A.C. 1993. La fauna acompañante de Hymeniacidon sanguinea (Grant, 1827) (Porifera: Demospongiae). Neotrópica 39: 3-10.

De Broyer C., Lowry J.K., Jażdżewski K., Robert H. 2007. Census of Antarctic Marine Life. Synopsis of the Amphipoda of the Southern Ocean. Part. 1. Catalogue of the Gammaridean and Corophiidean Amphipoda (Crustacea) of the Southern Ocean with distribution and ecological data. Bull. Inst. R. Sci. Nat. Belgique 77: 1-325

Duarte L.F.L., Nalesso R.C. 1996. The sponge Zygomycale parishii (Bowerbank) and its endobiotic fauna. Estuar. Coast. Shelf Sci. 42: $139-151$

Huang J.P., McClintock J.B., Amsler C.D., Huang Y.M. 2008. Mesofauna associated with the marine sponge Amphimedon viridis. Do its physical or chemical attributes provide a prospective refuge from fish predation? J. Exp. Mar. Biol. Ecol. 362: 95-100

Ilan M., Ben-Eliahu M.N., Galil B.S. 1994. Three deep water sponges from the eastern Mediterranean and their associated fauna. Ophelia 39(1): 45-54.

Johnston G. 1842. A History of British Sponges and Lithophytes. Edinburgh, W.H. Lizars. pp. xii, 1-264, pls I-XXV.

Kilgallen N.M. 2010. A new Antarctic species of Aristias Boeck (Crustacea, Amphipoda, Aristiidae), with remarks on the genus in Antarctica. Zootaxa 2426: 43-53.

Kjellin Green A. 2008. Invertebrate endofauna associated with sponge and octocoral epifauna at Gary's National Marine Sanctuary off the coast of Georgia. Ms. thesis, The Graduate School of the College of Charleston, $133 \mathrm{pp}$.

Klautau M., Monteiro L., Borojevic R. 2004. First occurrence of the genus Paraleucilla (Calcarea, Porifera) in the Atlantic Ocean: P. magna sp. nov. Zootaxa 710: 1-8

Klitgaard A.B. 1995. The fauna associated with outer shelf and 
upper slope sponges (Porifera, Demospongiae) at the Faroe Islands, Northeastern Atlantic. Sarsia 80: 1-22.

Klitgaard A.B. 1997. The distribution and habitats in the North Atlantic of two gnathiid species (Crustacea, Isopoda) and their reproductive biology in the Denmark Strait and north of Iceland. Medd. Grönland 47: 1-32.

Koukouras A., Voultsiadou-Koukoura E., Chintiroglou C., Dounas C. 1985. A comparison of the macrobenthic animal assemblages associated with seven sponge species. Cah. Biol. Mar. 26: 301-319.

Koukouras A., Russo A., Voultsiadou-Koukoura E., Dounas C., Chintiroglou C. 1992. Relationship of sponge macrofauna with the morphology of their hosts in the North Aegean Sea. Int. Rev. Gesamten Hydrobiol. 77: 609-619.

Koukouras A., Russo A., Voultsiadou-Koukoura E. 1996. Macrofauna associated with the sponge species of different morphology. Mar. Ecol. 14: 569-82.

LeCroy S.E. 2009. Colomastigidae. In: Lowry J.K., Myers A.A. (eds.), Benthic Amphipoda (Crustacea: Peracarida) of the Great Barrier Reef, Australia. Zootaxa 2260: 348-372.

Lévi C. 1960. Spongiaires des côtes occidentales africaines. Bull. Inst. Fr. Afr. Noire 22(3): 743-769.

Long E.R. 1968. The associates of four species of marine sponges of Oregon and Washington. Pacific Sci. 22: 347-351.

López Gappa J., Landoni N.A. 2005. Biodiversity of Porifera in the Southwest Atlantic between $35^{\circ} \mathrm{S}$ and $56^{\circ} \mathrm{S}$. Rev. Mus. Argentino Cs. Nat. 7: 191-219.

López Gappa J., Alonso G.M., Landoni N.A. 2006. Biodiversity of benthic Amphipoda (Crustacea: Peracarida) in the Southwest Atlantic between $35^{\circ} \mathrm{S}$ and $56^{\circ} \mathrm{S}$. Zootaxa 1342: 1-66.

Majer A.P., Trigo J.R., Duarte L.F.L. 2009. Evidence of an alarm signal in Ophiuroidea (Echinodermata). Mar. Biodivers. Rec. 2: e102. doi: $10.1017 /$ S1755267209001067

Monod T. 1926. Les Gnathiidae. Essai monographique (Morphologie, Biologie, Systématique). Mém. Soc. Sci. Nat. Maroc Zool. 13: $1-668$.

National Research Council, 2002. Effects of Trawling and Dredging on Seafloor Habitat. Committee on Ecosystem Effects of Fishing: Phase 1 - Effects of Bottom Trawling on Seafloor Habitats, Ocean Studies Board, Division on Earth and Life Studies. National Academy, Washington D. C., 126 pp.

Neves G., Omena E. 2003. Influence of sponge morphology on the composition of the polychaete associated fauna from Rocas Atoll, northeast Brazil. Coral Reefs 22: 123-129.

Neves B.M., Lima E.J.B., Perez C.D. 2007. Brittle Stars (Echinodermata: Ophiuroidea) associated with the Octocoral Carijoa riisei (Cnidaria: Anthozoa) from the Littoral of Pernambuco, Brazil. J. Mar. Biol. Assoc. U.K. 87: 1263-1267.

Ota Y., Tanaka K., Hirose E. 2008. Seasonal fluctuations of the sponge-dwelling gnathiid isopod Elaphognathia aff. cornigera. Crust. Res. 37: 14-25.

Padua A., Lanna E., Klautau M. 2010. Macrofauna inhabiting the sponge Paraleucilla magna (Porifera, Calcarea) in Brazil. VIII World Sponge Conference, Book of abstracts: 282.

Parker G., Paterlini C.M., Violante, R.A. 1997. El Fondo Marino. In: Boschi E.E. (ed.), El Mar Argentino y sus Recursos Pesqueros, Tomo 1. INIDEP, Mar del Plata, pp. 65-87.

Pawlik R.J. 1983. A Sponge-Eating Worm from Bermuda: Branchiosyllis oculata (Polychaeta, Syllidae). Mar. Ecol. 4: 65-79.

Pearse AS. 1950. Notes on the inhabitants of certain sponges at Bimini. Ecology 31: 149-51.

Poore, A.G.B., Watson M.J., de Nys R., Lowry J.K., Steinberg P.D. 2000. Patterns of host use among alga- and sponge-associated amphipods. Mar. Ecol. Prog. Ser. 208: 183-196.

Ribeiro S.M., Omena E.P., Muricy G. 2003. Macrofauna associated to Mycale microsigmatosa (Porifera, Demospongiae) in Rio de Janeiro State, SE Brazil. Estuar. Coast. Shelf Sci. 57: 951-959.

Rivas A.L. 2006. Quantitative estimation of the influence of surface thermal fronts over chlorophyll concentration at the Patagonian shelf. J. Mar. Sys. 63: 183-190.

Romero S.I., Piola A.R, Charo M., Eiras Garcia C.A. 2006. Chlorophyll a variability off Patagonia based on Sea WiFS data. $J$. Geophys. Res. 111: C05021. doi: 10.1029/2005JC003244

Rützler K. 1976. Ecology of Tunisian commercial sponges. Tethys 7: 249-264.

Rützler K. 1978. Sponges in coral reefs. In: Stoddard D.R., Johannes R.E. (eds.), Coral Reefs: Research Methods. Monographs on
Oceanographic Methodology 5. Paris, UNESCO, pp. 299-313.

Saffo M.B. 1992. Invertebrates in endosymbiotic associations. Am. Zool. 32: 557-565.

Sánchez M.A., Giberto D., Bremec C., Schejter L. 2011. The Patagonian scallop fishing grounds in shelf break frontal areas: the non assessed benthic fraction. Lat. Am. J. Aquat. Res. 39(1): $167-71$.

Sará M., Vacelet J. 1973. Ecologie des Demosponges. In: Grassé P.P. (ed.), Traité de Zoologie: Espongiaires, 3(1). Masson et Cie., Paris, pp. 462-576.

Schejter L., Calcinai B., Cerrano C., Bertolino M., Pansini M., Giberto D., Bremec C., 2006. Porifera from the Argentine Sea: diversity in Patagonian scallop beds. Ital. J. Zool. 73(4): 373-385.

Schejter L., Bremec C. 2007a. Benthic richness in the Argentine continental shelf: the role of Zygochlamys patagonica (Mollusca: Bivalvia: Pectinidae) as settlement substrate. J. Mar. Biol. Assoc. U.K. 87: 917-925.

Schejter L., Bremec C. 2007b. Did the epibenthic bycatch at the Patagonian scallop assemblage change after ten years of fishing? J. Shellfish Res. 26(4): 1341-1343.

Schejter L., Bremec C.S., Hernández D. 2008. Comparison between disturbed and undisturbed areas of the Patagonian scallop ( $Z y$ gochlamys patagonica) fishing ground "Reclutas" in the Argentine Sea. J. Sea Res. 60: 193-200.

Schejter L., Escolar M., Bremec C. 2011. Variability in epizoic colonization on Fusitriton magellanicus shells. J. Mar. Biol. Assoc. U.K. 91(4): 897-906.

Schmidt O. 1864. Supplement der Spongien des adriatischen Meeres. Enthaltend die Histologie und systematische Ergänzungen. Leipzig, Wilhelm Engelmann. pp. i-vi, 1-48, pls 1-4.

Simone L.R.L., Penchaszadeh P. 2008. Redescription of Hiatella meridionalis D’Orbigny, 1846 (Mollusca, Bivalvia, Hiatellidae) from Argentina. Pap. Avulsos Zool. 48: 119-127.

Skilleter G.A., Russell B.D., Degnan B.M., Garson M.J. 2005. Living in a potentially toxic environment: comparisons of endofauna in two congeneric sponges from the Great Barrier. Mar. Ecol. Prog. Ser. 304: 67-75.

Smit N.J., Davies A.J. 2004. The curious life-style of the parasitic stages of gnathiid isopods. Adv. Parasitol. 58: 289-391.

Smit N.J., Basson L., Van As J.G. 2003. Life cycle of the temporary fish parasite, Gnathia africana (Crustacea: Isopoda: Gnathiidae). Fol. Parasitol. 50: 135-142

Studer T. 1884. Isopoden, gesammelt während der Reise S.M.S. Gazelle um die Erde 1874-76. Abh. der Math.-phys. Klasse der Kgl. bayr. Akad. der wiss. 1883: 1-28.

Thiel M. 2000. Population and reproductive biology of two sibling amphipod species from ascidians and sponges. Mar. Biol. 137: 661-674.

Thomas J.D., Klebba, K.N. 2007. New species and host associations of commensal leucothoid amphipods from coral reefs in Florida and Belize (Crustacea: Amphipoda). Zootaxa 1494: 1-44.

Upton N.P.D. 1987. Asynchronous male and female life cycles in the sexually dimorphic, harem-forming isopod Paragnathia formica (Crustacea: Isopoda). J. Zool. 212: 677-690.

Van Soest R.W.M., Boury-Esnault N., Hooper J.N.A., Rützler K., de Voogd N.J., Alvarez de Glasby B., Hajdu E., Pisera A.B., Manconi R., Schoenberg C., Janussen D., Tabachnick K.R., Klautau M., Picton B., Kelly M. 2010. World Porifera database. Available from: http://www.marinespecies.org/porifera/ (accessed January, 2011).

Voultsiadou-Koukoura E, Koukouras A. 1993. Remarks on spongedecapod associations in the North Aegean Sea. Bios (Macedonia, Greece) 1: 251-256.

Wägele J.-W. 1988. Aspects of the life-cycle of the Antarctic fish parasite Gnathia calva Vanhöffen (Crustacea: Isopoda). Polar Biol. 8: 287-291.

Wendt P.H., van Dolah R., Rourke C.O. 1985. A comparative study of the invertebrate macrofauna associated with seven sponge and coral species collected from the south Atlantic Bight. $J$. Elisha Mitchell Sci. Soc. 101: 187-203.

Westinga E. HPC. 1981. The intrasponge fauna of Spheciospongia vesparia (Porifera, Demospongiae) at Curacao and Bonaire. Mar. Biol. 62: 139-50

White K.N., Thomas J.D. 2009. Leucothoidae. In: Lowry J.K., Myers A.A. (eds.), Benthic Amphipoda (Crustacea: Peracarida) of the Great Barrier Reef, Australia. Zootaxa 2260: 494-555.

Winfield I., Ortiz M. 2010. Colomastigids (Amphipoda: Gamma- 
ridea: Colomastigidae) from the Veracruz Coral Reef System, SW Gulf of Mexico, with a description of two new species associated with sponges. Sci. Mar. 74: 773-782.

Winfield I., Ortiz M., Cházaro-Olvera S. 2008. A new sponge-inhabiting amphipod species (Crustacea, Gammaridea, Sebidae) from the Veracruz Coral Reef System, southwestern Gulf of Mexico. Org. Divers. Evol. 9: 72.e1-72.e8.

Wulff J.L. 2006. Ecological interactions of marine sponges. Can. J. Zool. 84: 146-166.

Scient. ed.: M.J. Uriz.

Received August 17, 2011. Accepted March 30, 2012.

Published online September 28, 2012.

\section{SUPPLEMENTARY MATERIAL}

The following Appendix is available through the web page http://www.icm.csic.es/scimar/supplm/sm03490SMA.pdf

APPENDIX 1. - Endobiotic fauna of Porifera from several regions, considering the morphology of the sponge, bathymetric distribution, latitude, richness and dominant taxon group. Fishes and microbial symbionts were not considered. (1) The reference to the endobionts of this species does not provide a description of the general morphology. (2) The reference to the endobionts of this species does not provide a description of the general morphology, which is provided from another source in brackets. 
Mycale (Aegogropila) magellanica (Porifera: Demospongiae) in the southwestern Atlantic Ocean: endobiotic fauna and new distributional information

LAURA SCHEJTER, IGNACIO L. CHIESA, BRENDA L. DOTI and CLAUDIA BREMEC 
APPENDIX 1. - Endobiotic fauna of Porifera from several regions, considering the morphology of the sponge, bathymetric distribution, latitude, richness and dominant taxon group. Fishes and microbial symbionts were not considered. (1) The reference to the endobionts of this species does not provide a description of the general morphology. (2) The reference to the endobionts of this species does not provide a description of the general morphology, which is provided from another source in brackets.

\begin{tabular}{|c|c|c|c|c|c|c|}
\hline Species & Morphology & Location & Depth (m) & $\begin{array}{l}\mathrm{N}^{\circ} \text { associated } \\
\text { species (habits) }\end{array}$ & Dominant taxa & Source \\
\hline $\begin{array}{l}\text { Agelas clatrodes } \\
\text { (Schmidt, 1870) }\end{array}$ & Massive & $\begin{array}{c}\text { SW Atlantic } \\
\left.\text { (Rocas Atoll, } 3^{\circ} \mathrm{S}\right)\end{array}$ & $\begin{array}{l}\text { Intertidal pools and } \\
\text { semi-enclosed lagoon }\end{array}$ & No data & $\begin{array}{l}\text { Polychaeta } \\
\text { (16 taxa) }\end{array}$ & $\begin{array}{c}\text { Neves and } \\
\text { Omena (2003) }\end{array}$ \\
\hline $\begin{array}{l}\text { Agelas dispar } \\
\text { Duchassaing and } \\
\text { Michelotti, } 1864\end{array}$ & Massive & $\begin{array}{c}\text { SW Atlantic } \\
\text { (Rocas Atoll, } 3^{\circ} \mathrm{S} \text { ) }\end{array}$ & $\begin{array}{l}\text { Intertidal pools and } \\
\text { semi-enclosed lagoon }\end{array}$ & No data & $\begin{array}{l}\text { Polychaeta } \\
\text { (16 taxa) }\end{array}$ & $\begin{array}{c}\text { Neves and } \\
\text { Omena (2003) }\end{array}$ \\
\hline \multirow[t]{2}{*}{$\begin{array}{l}\text { Agelas oroides } \\
\text { (Schmidt, 1864) }\end{array}$} & (1) & $\begin{array}{l}\text { N Aegean Sea } \\
\left(40^{\circ} \mathrm{N}\right)\end{array}$ & $3-6$ & 61 & $\begin{array}{l}\text { Polychaeta } \\
\text { (32 taxa) }\end{array}$ & $\begin{array}{l}\text { Koukouras et al. } \\
\quad(1985)\end{array}$ \\
\hline & Massive, lobate & $\begin{array}{l}\text { N Aegean Sea } \\
\left(40^{\circ} \mathrm{N}\right)\end{array}$ & $15-20$ & $\begin{array}{l}135 \text { (mainly } \\
\text { endobionts) }\end{array}$ & Unavailable & $\begin{array}{l}\text { Koukouras et al. } \\
\text { (1996) }\end{array}$ \\
\hline $\begin{array}{l}\text { Aiolochroia crassa } \\
\text { (Hyatt, 1875) }\end{array}$ & Lobate & $\begin{array}{c}\text { SW Atlantic } \\
\left.\text { (Rocas Atoll, } 3^{\circ} \mathrm{S}\right)\end{array}$ & $\begin{array}{l}\text { Intertidal pools and } \\
\text { semi-enclosed lagoon }\end{array}$ & No data & $\begin{array}{l}\text { Polychaeta } \\
\text { (16 taxa) }\end{array}$ & $\begin{array}{c}\text { Neves and Omena } \\
\text { (2003) }\end{array}$ \\
\hline $\begin{array}{l}\text { Amphimedon compressa } \\
\text { (Duchassaing and } \\
\text { Michelotti, 1864) as } \\
\text { Haliclona rubens }\end{array}$ & (1) & $\begin{array}{l}\text { Caribbean Sea } \\
\text { (Bimini Is.) }\end{array}$ & $1-2$ & 11 & $\begin{array}{l}\text { Crustacea } \\
(6 \text { taxa) }\end{array}$ & Pearse (1950) \\
\hline $\begin{array}{l}\text { Amphimedon compressa } \\
\text { (Duchassaing and } \\
\text { Michelotti, 1864) }\end{array}$ & Lobate & $\begin{array}{c}\text { SW Atlantic } \\
\left.\text { (Rocas Atoll, } 3^{\circ} \mathrm{S}\right)\end{array}$ & $\begin{array}{l}\text { Intertidal pools and } \\
\text { semi-enclosed lagoon }\end{array}$ & No data & $\begin{array}{l}\text { Polychaeta } \\
\text { (16 taxa) }\end{array}$ & $\begin{array}{c}\text { Neves and Omena } \\
\text { (2003) }\end{array}$ \\
\hline \multirow{2}{*}{$\begin{array}{l}\text { Amphimedon viridis } \\
\text { Duchassaing and } \\
\text { Michelotti, } 1864\end{array}$} & (1) & $\begin{array}{l}\text { Gulf of Mexico } \\
\text { (Florida, } 29^{\circ} \mathrm{N} \text { ) }\end{array}$ & $1-2$ & $\begin{array}{l}10 \text { (endobionts } \\
\text { and epibionts) }\end{array}$ & $\begin{array}{l}\text { Crustacea } \\
\text { (7 taxa) }\end{array}$ & $\begin{array}{l}\text { Huang et al. } \\
\text { (2008) }\end{array}$ \\
\hline & Lobate & $\begin{array}{c}\text { SW Atlantic } \\
\text { (Rocas Atoll, } 3^{\circ} \mathrm{S}\end{array}$ & $\begin{array}{l}\text { Intertidal pools and } \\
\text { semi-enclosed lagoon }\end{array}$ & No data & $\begin{array}{l}\text { Polychaeta } \\
\text { (16 taxa) }\end{array}$ & $\begin{array}{c}\text { Neves and } \\
\text { Omena (2003) }\end{array}$ \\
\hline $\begin{array}{l}\text { Aplysina aerophoba } \\
\text { Nardo, } 1833\end{array}$ & Digitated & $\begin{array}{l}\text { N Aegean Sea } \\
\left(40^{\circ} \mathrm{N}\right)\end{array}$ & $3-6$ & 104 & $\begin{array}{l}\text { Crustacea } \\
\text { (39 taxa) }\end{array}$ & $\begin{array}{l}\text { Koukouras et al. } \\
\quad(1985)\end{array}$ \\
\hline as Verongia aerophoba & (1) & $\begin{array}{l}\text { N Aegean Sea } \\
\left(40^{\circ} \mathrm{N}\right)\end{array}$ & $15-20$ & $\begin{array}{l}184 \text { (mainly } \\
\text { endobionts) }\end{array}$ & No data & $\begin{array}{c}\text { Koukouras et al. } \\
\text { (1996) }\end{array}$ \\
\hline Aplysina sp. & Lobate & $\begin{array}{c}\text { SW Atlantic } \\
\left.\text { (Rocas Atoll, } 3^{\circ} \mathrm{S}\right)\end{array}$ & $\begin{array}{l}\text { Intertidal pools and } \\
\text { semi-enclosed lagoon }\end{array}$ & No data & $\begin{array}{l}\text { Polychaeta } \\
\text { (16 taxa) }\end{array}$ & $\begin{array}{c}\text { Neves and Omena } \\
\text { (2003) }\end{array}$ \\
\hline $\begin{array}{l}\text { Axinella cannabina } \\
\text { (Esper, 1794) }\end{array}$ & $\begin{array}{l}\text { Erect, irregularly } \\
\text { branched }\end{array}$ & $\begin{array}{l}\text { N Aegean Sea } \\
\left(40^{\circ} \mathrm{N}\right)\end{array}$ & $15-20$ & $\begin{array}{l}84 \text { (mainly } \\
\text { endobionts) }\end{array}$ & No data & $\begin{array}{l}\text { Koukouras et al. } \\
\quad(1996)\end{array}$ \\
\hline $\begin{array}{l}\text { Axinella infundibuliformis } \\
\text { (Linnaeus, 1759) } \\
\text { as Tragosia } \\
\text { infundibuliformis }\end{array}$ & $\begin{array}{l}\text { Elastic, } \\
\text { foliaceous or } \\
\text { funnel-shaped }\end{array}$ & $\begin{array}{l}\text { NE Atlantic } \\
\text { (Faroe Islands, } \\
\left.62^{\circ} \mathrm{N}\right)\end{array}$ & $157-780$ & $\begin{array}{l}15 \text { (mostly } \\
\text { epifauna) }\end{array}$ & $\begin{array}{l}\text { Polychaeta } \\
\text { (5 taxa) }\end{array}$ & Klitgaard (1995) \\
\hline $\begin{array}{l}\text { Axinella polycapella } \mathrm{S} \\
\text { de Laubenfels, } 1953\end{array}$ & $\begin{array}{l}\text { Slightly upright, } \\
\text { ew short branches }\end{array}$ & $\begin{array}{c}\text { NW Atlantic, } \\
31^{\circ} \mathrm{N}\end{array}$ & $58-66$ & 19 & $\begin{array}{l}\text { Crustacea } \\
\text { (14 taxa) }\end{array}$ & $\begin{array}{l}\text { Kjellin Green } \\
\text { (2008) }\end{array}$ \\
\hline $\begin{array}{l}\text { Axinella rugosa } \\
\text { (Bowerbank, 1866) } \\
\text { as Phakellia rugosa }\end{array}$ & $\begin{array}{l}\text { Elastic, } \\
\text { ramified }\end{array}$ & $\begin{array}{l}\text { NE Atlantic } \\
\text { (Faroe Islands, } \\
\left.62^{\circ} \mathrm{N}\right)\end{array}$ & $157-780$ & $\begin{array}{l}28 \text { (mostly } \\
\text { epifauna) }\end{array}$ & $\begin{array}{l}\text { Ophiuroidea } \\
\text { (6 taxa) }\end{array}$ & Klitgaard (1995) \\
\hline $\begin{array}{l}\text { Clathria (Clathria) } \\
\text { prolifera (Ellis and } \\
\text { Solander, 1786) as } \\
\text { Microciona prolifera }\end{array}$ & $\begin{array}{l}\text { Erect, branching } \\
\text { and bushy }\end{array}$ & $\begin{array}{l}\text { NW Atlantic, } \\
\text { Washington }\end{array}$ & Subtidal & 52 & Crustacea & Long (1968) \\
\hline $\begin{array}{l}\text { Clathria (Thalysias) } \\
\text { schoemus } \\
\text { (de Laubenfels, 1936) } \\
\text { as Aulospongus schoemu }\end{array}$ & Branching & $\begin{array}{l}\text { Caribbean Sea } \\
\text { (Bimini Is.) }\end{array}$ & $1-2$ & 3 & $\begin{array}{l}\text { Polychaeta } \\
\text { (2 taxa) }\end{array}$ & Pearse (1950) \\
\hline $\begin{array}{l}\text { Geodia barretti } \\
\text { Bowerbank, } 1858\end{array}$ & $\begin{array}{l}\text { Solid, } \\
\text { massive }\end{array}$ & $\begin{array}{c}\text { NE Atlantic } \\
\left(\text { Faroe Islands, } 62^{\circ} \mathrm{N}\right)\end{array}$ & $157-780$ & $\begin{array}{l}8 \text { (mostly } \\
\text { epifauna) }\end{array}$ & $\begin{array}{l}\text { Polychaeta } \\
\text { (3 taxa) }\end{array}$ & Klitgaard (1995) \\
\hline
\end{tabular}




\begin{tabular}{|c|c|c|c|c|c|c|}
\hline Species & Morphology & Location & Depth (m) & $\begin{array}{l}\mathrm{N}^{\circ} \text { associated } \\
\text { species (habits) }\end{array}$ & Dominant taxa & Source \\
\hline $\begin{array}{l}\text { Geodia cydonium } \\
\text { (Jameson, 1811) }\end{array}$ & $\begin{array}{l}\text { (2) Solid, } \\
\text { globular (from } \\
\text { Johnston 1842) }\end{array}$ & $\begin{array}{l}\text { Aegean Sea } \\
\left(40^{\circ} \mathrm{N}\right)\end{array}$ & $3-6$ & 98 & $\begin{array}{l}\text { Crustacea } \\
\text { (40 taxa) }\end{array}$ & $\begin{array}{l}\text { Koukouras et al. } \\
\quad \text { (1985) }\end{array}$ \\
\hline $\begin{array}{l}\text { Geodia macandrewii } \\
\text { Bowerbank, } 1858\end{array}$ & $\begin{array}{l}\text { Solid, } \\
\text { massive }\end{array}$ & $\begin{array}{c}\text { NE Atlantic } \\
\left(\text { Faroe Islands, } 62^{\circ} \mathrm{N}\right)\end{array}$ & $157-780$ & $\begin{array}{l}57 \text { (mostly } \\
\text { epifauna) }\end{array}$ & $\begin{array}{l}\text { Polychaeta } \\
\text { (21 taxa) }\end{array}$ & Klitgaard (1995) \\
\hline Geodia sp. & $\begin{array}{l}\text { Solid, } \\
\text { massive }\end{array}$ & $\begin{array}{c}\text { NE Atlantic } \\
\text { (Faroe Islands, } 62^{\circ} \mathrm{N} \text { ) }\end{array}$ & $157-780$ & $\begin{array}{l}23 \text { (mostly } \\
\text { epifauna) }\end{array}$ & $\begin{array}{l}\text { Polychaeta } \\
\text { (6 taxa) }\end{array}$ & Klitgaard (1995) \\
\hline $\begin{array}{l}\text { Halichondria panicea } \\
\text { (Pallas, 1966) }\end{array}$ & Encrusting & NW Atlantic & Intertidal & 68 & Crustacea & Long (1968) \\
\hline Haliclona sp.1 & $\begin{array}{l}\text { Amorphous, } \\
\text { himney-like oscules }\end{array}$ & $\begin{array}{l}\text { SW Australia } \\
\left(30-40^{\circ} \mathrm{S}\right)\end{array}$ & $10-15$ & 23 (endobionts) & $\begin{array}{l}\text { Crustacea } \\
(15 \text { taxa })\end{array}$ & Abdo (2007) \\
\hline Haliclona sp.2 & $\begin{array}{l}\text { Mound-shaped, } \\
\text { compact }\end{array}$ & $\begin{array}{l}\text { SW Australia } \\
\left(30-40^{\circ} \mathrm{S}\right)\end{array}$ & $10-15$ & 23 (endobionts) & $\begin{array}{l}\text { Crustacea } \\
(15 \text { taxa) }\end{array}$ & Abdo (2007) \\
\hline $\begin{array}{l}\text { Hippospongia } \\
\text { communis } \\
\text { (Lamarck, 1814) }\end{array}$ & $\begin{array}{l}\text { (2) } \\
\text { Massive, compact, } \\
\text { and usually roughly } \\
\text { pherical (from Cook } \\
\text { nd Bergquist 2002a) }\end{array}$ & $\begin{array}{l}\text { Mediterranean, } \\
\text { Tunisia } \\
\text { T }\end{array}$ & 14 & 24 & $\begin{array}{l}\text { Crustacea } \\
\text { (11 taxa) }\end{array}$ & Rützler (1976) \\
\hline $\begin{array}{l}\text { Hymeniacidon } \\
\text { sanguinea } \\
\text { (Grant, 1827) } \\
\text { sensu Burton, } 1840 \\
\text { (currently, this species n }\end{array}$ & $\begin{array}{r}\text { Encrusting } \\
\text { needs revision) }\end{array}$ & $\begin{array}{l}\text { SW Atlantic } \\
\text { (Mar del Plata, } \\
\left.38^{\circ} \mathrm{S}\right)\end{array}$ & Intertidal ponds & $\begin{array}{l}33 \text { (endobionts } \\
\text { and epibionts) }\end{array}$ & $\begin{array}{l}\text { Crustacea } \\
\text { (12 taxa) }\end{array}$ & $\begin{array}{c}\text { Cuartas and } \\
\text { Excoffon (1993) }\end{array}$ \\
\hline \multirow{2}{*}{$\begin{array}{l}\text { Ircinia felix } \\
\text { (Duchassaing and } \\
\text { Michelotti, 1864) }\end{array}$} & Lobate & $\begin{array}{c}\text { SW Atlantic } \\
\left(\text { Rocas Atoll, } 3^{\circ} \mathrm{S}\right)\end{array}$ & $\begin{array}{l}\text { Intertidal pools and } \\
\text { semi-enclosed lagoon }\end{array}$ & no data & $\begin{array}{l}\text { Polychaeta } \\
\text { (16 taxa) }\end{array}$ & $\begin{array}{c}\text { Neves and Omena } \\
\text { (2003) }\end{array}$ \\
\hline & & NO Atlantic, $31^{\circ} \mathrm{N}$ & $58-66$ & 84 & $\begin{array}{l}\text { Crustacea } \\
\text { (31 taxa) }\end{array}$ & $\begin{array}{l}\text { Kjellin Green } \\
\text { (2008) }\end{array}$ \\
\hline $\begin{array}{l}\text { Ircinia oros } \\
\text { (Schmidt, 1864) } \\
\text { (from the original } \\
\text { description) }\end{array}$ & $\begin{array}{c}\text { (2) } \\
\text { Massive, rounded }\end{array}$ & $\begin{array}{l}\text { Mediterranean, } \\
\text { Tunisia }\end{array}$ & 14 & 6 & Polychaeta & Rützler (1976) \\
\hline $\begin{array}{l}\text { Ircinia retidermata } \\
\text { Pulitzer-Finali and } \\
\text { Pronzato, } 1981\end{array}$ & Hemispherical & E Mediterranean & 830 & 4 & $\begin{array}{l}\text { Polychaeta } \\
\text { (3 taxa) }\end{array}$ & Ilan et al. (1994) \\
\hline $\begin{array}{l}\text { Ircinia strobillina } \\
\text { (Lamarck, 1816) } \\
\text { as Hiricina strobilina }\end{array}$ & $\begin{array}{l}\text { Solid, firm } \\
\text { (loggerhead) }\end{array}$ & $\begin{array}{l}\text { Caribbean Sea } \\
\text { (Bimini Is.) }\end{array}$ & $1-2$ & 30 & $\begin{array}{l}\text { Polychaeta } \\
\text { (11 taxa) }\end{array}$ & Pearse (1950) \\
\hline $\begin{array}{l}\text { Ircinia variabilis } \\
\text { (Schmidt, 1864) }\end{array}$ & $\begin{array}{l}\text { (2) } \\
\text { Variable, massive } \\
\text { or thickly encrusting } \\
\text { (from the original } \\
\text { description) }\end{array}$ & $\begin{array}{l}\text { Mediterranean, } \\
\text { Tunisia }\end{array}$ & 14 & 16 & $\begin{array}{l}\text { Crustacea } \\
(8 \text { taxa) }\end{array}$ & Rützler (1976) \\
\hline $\begin{array}{l}\text { Iotrochota birotulata } \\
\text { (Higgin, 1877) } \\
\text { as Iotrochota brotulata }\end{array}$ & Branching & $\begin{array}{l}\text { Caribbean Sea } \\
\text { (Bimini Is.) }\end{array}$ & $1-2$ & 4 & $\begin{array}{l}\text { Crustacea } \\
(2 \text { taxa })\end{array}$ & Pearse (1950) \\
\hline $\begin{array}{l}\text { Isops phlegraei } \\
\text { Sollas, } 1880\end{array}$ & Solid, massive & $\begin{array}{c}\text { NE Atlantic } \\
\left.\text { (Faroe Islands, } 62^{\circ} \mathrm{N}\right)\end{array}$ & $157-780$ & $\begin{array}{l}44 \text { (mostly } \\
\text { epifauna) }\end{array}$ & $\begin{array}{l}\text { Bryozoa } \\
(11 \text { taxa) }\end{array}$ & Klitgaard (1995) \\
\hline $\begin{array}{l}\text { Mycale (Z.) angulosa } \\
\text { (Duchassaing and } \\
\text { Michelotti, 1864) as } \\
\text { Zygomycale parishi }\end{array}$ & $\begin{array}{l}\text { Globose to } \\
\text { fistulous }\end{array}$ & $\begin{array}{c}\text { SW Atlantic } \\
\left(\text { Sao Paulo, } 23^{\circ} \mathrm{S}\right)\end{array}$ & Subtidal & 98 & $\begin{array}{l}\text { Polychaeta } \\
\text { (39 taxa) }\end{array}$ & $\begin{array}{c}\text { Duarte and } \\
\text { Nalesso (1996) }\end{array}$ \\
\hline $\begin{array}{l}\text { Mycale (A.) magellanica } \\
\text { (Ridley, 1881) }\end{array}$ & Massive & $\begin{array}{l}\text { SW Atlantic, } \\
\text { Argentina }\end{array}$ & $103-107$ & $\begin{array}{l}23 \text { (mostly } \\
\text { endobionts) }\end{array}$ & $\begin{array}{l}\text { Crustacea } \\
(10 \text { taxa) }\end{array}$ & Present study \\
\hline
\end{tabular}




\begin{tabular}{|c|c|c|c|c|c|c|}
\hline Species & Morphology & Location & Depth (m) & $\begin{array}{l}\mathrm{N}^{\circ} \text { associated } \\
\text { species (habits) }\end{array}$ & Dominant taxa & Source \\
\hline $\begin{array}{l}\text { Mycale }(C .) \\
\text { microsigmatosa } \\
\text { Arndt, } 1927\end{array}$ & $\begin{array}{l}\text { Encrusting, } \\
\text { can be massive }\end{array}$ & $\begin{array}{l}\text { SW Atlantic } \\
\text { (Rio de Janeiro, } \\
23^{\circ} \mathrm{S} \text { ) }\end{array}$ & $1-5$ & $\begin{array}{l}75 \text { (endobionts } \\
\text { and epibionts) }\end{array}$ & $\begin{array}{l}\text { Crustacea } \\
\text { (31 taxa) }\end{array}$ & $\begin{array}{l}\text { Ribeiro et al. } \\
\text { (2003) }\end{array}$ \\
\hline $\begin{array}{l}\text { Mycale (A.) syrinx } \\
\text { (Schmidt, 1862) }\end{array}$ & $\begin{array}{l}\text { (2) } \\
\text { Erect, branched } \\
\text { (from Lévi 1960) }\end{array}$ & N Aegean Sea & Not given & No data & $\begin{array}{l}\text { Crustacea } \\
(6 \text { taxa) }\end{array}$ & $\begin{array}{c}\text { Voultsiadou- } \\
\text { Koukoura and } \\
\text { Koukouras (1993) }\end{array}$ \\
\hline $\begin{array}{l}\text { Paraleucilla magna } \\
\text { Klatau, Monteiro } \\
\text { and Borojevic } 2004\end{array}$ & $\begin{array}{l}\text { (2) } \\
\text { Massive (from the } \\
\text { original description) }\end{array}$ & $\begin{array}{c}\text { SW Atlantic } \\
\text { (Rio de Janeiro, } \\
\left.23^{\circ} \mathrm{S}\right)\end{array}$ & Harbour areas & 48 & $\begin{array}{l}\text { Crustacea } \\
\text { (11 taxa) }\end{array}$ & $\begin{array}{l}\text { Padua et al. } \\
\quad(2010)\end{array}$ \\
\hline $\begin{array}{l}\text { Petrosia ficiformis } \\
\text { (Poiret, 1789) }\end{array}$ & $\begin{array}{c}\text { (2) } \\
\text { Variable; usually } \\
\text { pherical and cylindrical } \\
\text { (from Bavestrelo and } \\
\text { Sara 1992) }\end{array}$ & $\begin{array}{l}\text { N Aegean Sea } \\
\left(40^{\circ} \mathrm{N}\right)\end{array}$ & $3-6$ & 91 & $\begin{array}{l}\text { Crustacea } \\
\text { (43 taxa) }\end{array}$ & $\begin{array}{c}\text { Koukouras et al. } \\
\text { (1985) }\end{array}$ \\
\hline $\begin{array}{l}\text { Phakellia robusta } \\
\text { Bowerbank, } 1866\end{array}$ & $\begin{array}{l}\text { Elastic, foliaceous } \\
\text { or funnel-shaped }\end{array}$ & $\begin{array}{l}\text { NE Atlantic } \\
\text { (Faroe Islands, } \\
\left.62^{\circ} \mathrm{N}\right)\end{array}$ & $157-780$ & $\begin{array}{l}42 \text { (mostly } \\
\text { epifauna) }\end{array}$ & $\begin{array}{l}\text { Bryozoa } \\
\text { (13 taxa) }\end{array}$ & Klitgaard (1995) \\
\hline $\begin{array}{l}\text { Phakellia ventilabrun } \\
\text { (Linnaeus, 1767) }\end{array}$ & $\begin{array}{c}m \text { Elastic, foliaceous } \\
\text { or funnel-shaped }\end{array}$ & $\begin{array}{l}\text { NE Atlantic } \\
\text { (Faroe Islands, } \\
\left.62^{\circ} \mathrm{N}\right)\end{array}$ & $157-780$ & $\begin{array}{l}22 \text { (mostly } \\
\text { epifauna) }\end{array}$ & $\begin{array}{l}\text { Bryozoa } \\
\text { (7 taxa) }\end{array}$ & Klitgaard (1995) \\
\hline Plakortis sp. & Encrusting & $\begin{array}{c}\text { SW Atlantic } \\
\text { (Rocas Atoll, } 3^{\circ} \mathrm{S} \text { ) }\end{array}$ & $\begin{array}{c}\text { Intertidal pools } \\
\text { and semi-enclosed } \\
\text { lagoon }\end{array}$ & No data & $\begin{array}{l}\text { Polychaeta } \\
\text { (16 taxa) }\end{array}$ & $\begin{array}{c}\text { Neves and } \\
\text { Omena (2003) }\end{array}$ \\
\hline Plakortis sp. & Massive & $\begin{array}{c}\text { SW Atlantic } \\
\left.\text { (Rocas Atoll, } 3^{\circ} \mathrm{S}\right)\end{array}$ & $\begin{array}{c}\text { Intertidal pools } \\
\text { and semi-enclosed } \\
\text { lagoon }\end{array}$ & no data & $\begin{array}{l}\text { Polychaeta } \\
\text { (16 taxa) }\end{array}$ & $\begin{array}{c}\text { Neves and } \\
\text { Omena (2003) }\end{array}$ \\
\hline $\begin{array}{l}\text { Ptilocaulis walpersi } \\
\text { (Duchassaing and } \\
\text { Michelotti, 1864) }\end{array}$ & Upright, branched & $\begin{array}{l}\text { NW Atlantic, } \\
31^{\circ} \mathrm{N}\end{array}$ & $58-66$ & 60 & $\begin{array}{l}\text { Crustacea } \\
\text { (23 taxa) }\end{array}$ & $\begin{array}{c}\text { Kjellin Green } \\
(2008)\end{array}$ \\
\hline $\begin{array}{l}\text { Sarcotragus fasciculd } \\
\text { (Pallas, 1766) as } \\
\text { Ircinia fasciculata }\end{array}$ & $\begin{array}{l}\text { atus (2) } \\
\text { Massive, irregular, } \\
\text { and encrusting; } \\
\text { usually }\end{array}$ & $\begin{array}{l}\text { N Aegean Sea } \\
\left(40^{\circ} \mathrm{N}\right)\end{array}$ & $3-6$ & 151 & $\begin{array}{l}\text { Polychaeta } \\
\text { (61 taxa) }\end{array}$ & $\begin{array}{c}\text { Koukouras et al. } \\
\text { (1985) }\end{array}$ \\
\hline as I. fasciculata & $\begin{array}{l}\text { upright and } \\
\text { digitate (from Cook and } \\
\text { Bergquist 2002b) }\end{array}$ & $\begin{array}{l}\text { Mediterranean, } \\
\text { Tunisia }\end{array}$ & 14 & 13 & $\begin{array}{l}\text { Crustacea } \\
(7 \text { taxa) }\end{array}$ & Rützler (1976) \\
\hline $\begin{array}{l}\text { Sarcotragus foetidus } \\
\text { (Schmidt, 1862) } \\
\text { as Ircinia muscarum }\end{array}$ & (1) & $\begin{array}{l}\text { N Aegean Sea } \\
\left(40^{\circ} \mathrm{N}\right)\end{array}$ & $3-6$ & 90 & $\begin{array}{l}\text { Polychaeta and } \\
\text { Crustacea } \\
\text { (37 taxa each) }\end{array}$ & $\begin{array}{l}\text { Koukouras } \\
\text { et al. }(1985)\end{array}$ \\
\hline as I. muscarum & & $\begin{array}{l}\text { Mediterranean, } \\
\text { Tunisia }\end{array}$ & 14 & 14 & $\begin{array}{l}\text { Crustacea } \\
\text { (10 taxa) }\end{array}$ & Rützler (1976) \\
\hline $\begin{array}{l}\text { as Sarcotragus } \\
\text { muscarum }\end{array}$ & Massive, globular & E Mediterranean & 830 & 4 & $\begin{array}{l}\text { Polychaeta } \\
\text { (4 taxa) }\end{array}$ & Ilan et al. (1994) \\
\hline \multirow{2}{*}{$\begin{array}{l}\text { Spheciospongia } \\
\text { vesparium } \\
\text { (Lamarck, 1815) } \\
\text { as Spheciospongia } \\
\text { vesparia }\end{array}$} & \multirow{2}{*}{$\begin{array}{l}\text { Solid, firm, } \\
\text { hemispherical } \\
\text { to barrel-shaped } \\
\text { (loggerhead) }\end{array}$} & $\begin{array}{c}\text { Caribbean Sea } \\
\text { (Bimini Is.) }\end{array}$ & $1-2$ & 9 & $\begin{array}{l}\text { Crustacea } \\
(9 \text { taxa) }\end{array}$ & Pearse (1950) \\
\hline & & $\begin{array}{l}\text { (Curacao and } \\
\text { Bonaire Is.) }\end{array}$ & $3-60$ & 26 & $\begin{array}{l}\text { Crustacea } \\
(18 \text { taxa) }\end{array}$ & $\begin{array}{l}\text { Westinga and } \\
\text { Hoetjes (1981) }\end{array}$ \\
\hline $\begin{array}{l}\text { Spongia officinalis } \\
\text { Linnaeus, } 1759\end{array}$ & $\begin{array}{c}(2) \\
\text { Variable, } \\
\text { usually massive } \\
\text { spherical, lamellate, } \\
\text { caliculate, or low } \\
\text { d spreading (from Cook } \\
\text { and Bergquist 2002a) }\end{array}$ & $\begin{array}{l}\text { N Aegean Sea } \\
\left(40^{\circ} \mathrm{N}\right)\end{array}$ & $3-6$ & 89 & $\begin{array}{l}\text { Polychaeta } \\
\text { (36 taxa) }\end{array}$ & $\begin{array}{c}\text { Koukouras et al. } \\
\text { (1985) }\end{array}$ \\
\hline
\end{tabular}


ENDOFAUNA OF MYCALE (A.) MAGELLANICA • S5

\begin{tabular}{|c|c|c|c|c|c|c|}
\hline Species & Morphology & Location & Depth (m) & $\begin{array}{l}\mathrm{N}^{\circ} \text { associated } \\
\text { species (habits) }\end{array}$ & Dominant taxa & Source \\
\hline $\begin{array}{lr}\text { Spongia zimocca } \\
\text { Schmidt, 1862 } \\
& \text { ge } \\
& \text { Castrits }\end{array}$ & $\begin{array}{l}\text { (2) } \\
\text { Variable, massive, } \\
\text { senerally irregularl } \\
\text { lobate (from } \\
\text { tsi-Catharios } \text { et al. }\end{array}$ & $\begin{array}{l}\text { Mediterranean, } \\
\text { Tunisia } \\
\text { 2001) }\end{array}$ & 14 & 13 & $\begin{array}{l}\text { Crustacea } \\
\text { (6 taxa) }\end{array}$ & Rützler (1976) \\
\hline $\begin{array}{l}\text { Stryphnus ponderosus } \\
\text { (Bowerbank, 1866) }\end{array}$ & $\begin{array}{l}\text { Solid, } \\
\text { massive }\end{array}$ & $\begin{array}{c}\text { NE Atlantic } \\
\left(\text { Faroe Islands, } 62^{\circ} \mathrm{N}\right)\end{array}$ & $157-780$ & $\begin{array}{l}122 \text { (mostly } \\
\text { epifauna) }\end{array}$ & $\begin{array}{l}\text { Polychaeta } \\
\text { (35 taxa) }\end{array}$ & $\begin{array}{c}\text { Klitgaard } \\
(1995)\end{array}$ \\
\hline $\begin{array}{l}\text { Suberites latus } \\
\text { Lambe, } 1893 \text { as S. lata }\end{array}$ & Massive, tough & NW Atlantic & $5-10$ & 25 & Polychaeta & Long (1968) \\
\hline $\begin{array}{l}\text { Thenea levis } \\
\text { Lendenfeld, } 1907\end{array}$ & Solid, elongate & $\begin{array}{c}\text { NE Atlantic } \\
\left(\text { Faroe Islands, } 62^{\circ} \mathrm{N}\right)\end{array}$ & $157-780$ & $\begin{array}{l}108 \text { (mostly } \\
\text { epifauna) }\end{array}$ & $\begin{array}{l}\text { Polychaeta } \\
\text { (38 taxa) }\end{array}$ & Klitgaard (1995) \\
\hline $\begin{array}{l}\text { Thenea valdiviae } \\
\text { Lendenfeld, } 1907\end{array}$ & $\begin{array}{l}\text { Solid, spherical } \\
\text { or lump-formed }\end{array}$ & $\begin{array}{c}\text { NE Atlantic } \\
\left.\text { (Faroe Islands, } 62^{\circ} \mathrm{N}\right)\end{array}$ & $157-780$ & $\begin{array}{l}90 \text { (mostly } \\
\text { epifauna) }\end{array}$ & $\begin{array}{l}\text { Polychaeta } \\
\text { (41 taxa) }\end{array}$ & Klitgaard (1995) \\
\hline $\begin{array}{l}\text { Topsentia ophiraphidite } \\
\text { (de Laubenfels, 1934) }\end{array}$ & es Massive & $\begin{array}{c}\text { SW Atlantic } \\
\text { (Rocas Atoll, } 3^{\circ} \mathrm{S} \text { ) }\end{array}$ & $\begin{array}{c}\text { Intertidal pools } \\
\text { and semi-enclosed } \\
\text { lagoon }\end{array}$ & No data & $\begin{array}{l}\text { Polychaeta } \\
\text { (16 taxa) }\end{array}$ & $\begin{array}{c}\text { Neves and } \\
\text { Omena (2003) }\end{array}$ \\
\hline
\end{tabular}

